\title{
小腸代謝研究の現状と問題点
}

\author{
小村弘

\section{Current Status and Critical Issues on the Investigation of Small Intestinal Metabolism}

\author{
Hiroshi KOMURA \\ Department of Pharmacokinetics, Research Center Kyoto, Bayer Yakuhin Ltd., Kyoto
}

\begin{abstract}
Summary: Recently, pharmacokinetic analysis in clinical study has indicated that small intestinal metabolisms of certain drugs give a great impact on their exposures due to extensive first-pass effects particularly by CYP3A4. However, the in vitro metabolic activities in the small intestinal microsomes are, in general, lower than the relevant hepatic activities, and the intestinal extraction ratio predicted from the activities appeared to be inconsistent with the in vivo data. The reason for this may lie in the fact that both methodologies for the estimations from in vitro and in vivo have some issues (involvement of protein binding and effect of inducers/inhibitors on Q, respectively) to be clarified, or P-glycoprotein with the similar substrate specificity to CYP3A might be involved in the first pass metabolism. The detailed studies in an animal with a comparable CYP3A activity to human will be required to elucidate the contribution of small intestinal first-pass to overall metabolism.
\end{abstract}

Key words: Small intestinal metabolism, First-pass metabolism, P450s, CYP3A, P-glycoprotein, Species difference

\section{はじめに}

小腸初回通過代謝に関する in vitro から in vivoの予 測については, 1982 年にP. Klippert らによって phenacetinのラット小腸代謝活性から得られた小腸抽 出率が実測値と一致することが報告されている1).しか しながら小腸代謝が初回通過効果に関わっているとの認 識は一般に乏しく, 薬物動態研究の表舞台へ登場するま でにはその後約 10 年近くの歳月を待たなければならな かった. 1992 年にJ. C. Kolarらによって, 小腸 CYP3A による cyclosporine の初回通過代謝の可能性 ${ }^{2)}$ が報告されて以来, ヒトにおける初回通過代謝に小腸代 謝が寄与しているとの知見が数多く報告されている ${ }^{3-8)}$. これらに対して，in vivoの小腸初回通過代謝を説明す るのに十分な in vitro 代謝活性が得られているか？ と
いった疑問，および小腸初回通過代謝が過大評価されて いる可能性 ${ }^{9)}$ が指摘されている. そこで本稿では in vitro および in vivoでの小腸代謝の評価の現状を紹介す るとともに，その問題点を述べる.

\section{1. 小腸での P450 活性は肝臓より低い?}

P450 は mucosal crypts に存在する未成熟な epithelial cell ではほとんど認められず, epithelial cell が villous の tip 側へ成熟しながら移動する過程で合成され る10,11). 最も高い P450 含量は villous の tip 側において 認められ，その濃度は十二指腸および空腸から小腸下部 にかけて減少している12)。したがって in vitro 代謝実験 に使用される生体試料は小腸上部の villous tip の mucosa から調製される，さらにミクロソーム調製時に protease による分解を受けて活性が低下することから，

\footnotetext{
一こむら ひろし

小村 弘: 1983 年大阪府立大学大学院農学研究科修士課程修了. 現在, バイエル薬品 中央研究所薬物動態分野. 主任研究員として, 探索代謝試験を行っています. 探索試験の新しいアイディアをフランクに話合える場所があれば, と思うのですが!!
} 
protease inhibitor として EDTA, p-methylphenylsulfonyl floride または trypsin inhibitor など11,12)を用いて ミクロソームを調製するか, または単離した enterocyteが使用されている13)。ヒト小腸の P450 濃度は 肝蔵と比較して低く $0.055 \sim 0.14 \mathrm{nmol} / \mathrm{mg}$ protein であ り 13,14$)$, これは肝臟中濃度の $16 \sim 17 \%$ に相当する. 肝 と同様に小腸にも CYP1A1, 1B1, 2C, 2D6, 2E1，3A4 お よび $3 \mathrm{~A} 5$ の mRNA は検出されているが, タンパクレ ベルでは CYP1A1，2C および $3 \mathrm{~A} 4 / 5$ などが検出され るに過ぎない15)．M. F. Pain らは，十二指腸において CYP3A4 含量は $30.6 \mathrm{pmol} / \mathrm{mg}$ proteinであり, 総 $\mathrm{P} 450$ 含量 $60 \mathrm{pmol} / \mathrm{mg}$ protein の約半分を占めている ことを示した ${ }^{12)}$. 一方, ラット小腸上部における 4450 含量は $0.046 \sim 0.115 \mathrm{nmol} / \mathrm{mg}$ protein であり ${ }^{16-19)}$, 肝 蔵の $5.7 \sim 11.5 \%$ にしか過ぎない. 主な P450 分子種は CYP1A および2B であり，ヒトでの主たる P450であ る CYP3A の割合は比較的少ない20).

CYP3A によって代謝される薬物について，その小腸 ミクロソームをたは enterocytes における速度論的パラ メータをたは代謝活性8,13,14,21-26)を Table I に示した。

Oxodipine を除いて $\mathrm{km}$ 值は $2 \sim 12 \mu \mathrm{M}$ であり, 親和性 が比較的高かったのに対し， $\mathrm{V}_{\max }$ 值には 100 倍以上の 差が認められた. 小腸と肝蔵のパラメータ值を比較した 場合, すべての薬物の $\mathrm{km}$ 值は両ミクロソーム間でほほ 等しく, homology の高いCYP3A が両代謝反応に関与 しているものと考えられた．K. L. Lown らは小腸およ び肝蔵の CYP3A4 の cDNA の塩基配列が等しく, 同一 のCYP3A4 タンパクが発現している可能性を27)示唆し ている. 小腸での $\mathrm{V}_{\max }$ は terfenadine, midazolam, lovastatin 抢よび oxodipine で肝蔵よりも小さく 10 30\%である.一方, indinavir, cyclosporine 打よび rifabutin の $\mathrm{V}_{\max }$ は小腸および肝臓間でほほ等しく,さ らに erythromycin の代謝活性も両組織でほとんど差が ない.P450の小腸および肝臟での発現量から考えて小 腸代謝活性は肝臓よりも低いと思われるが，CYP3A4 の基質においては一概にそうとはいいきれない。

\section{2. 小腸代謝活性の特徵}

肝臓における薬物代謝の種差に関しては, P450 分子 種の組成比, さらに各分子種に特異的な基質を用いた代 謝活性など，詳細な検討がなされている．これに対して 小腸薬物代謝に関する種差の報告はきわめて少ない，著 者らはヒトに扔いて CYP3A4 で代謝される nisoldipine の小腸代謝活性の種差について, ラット，イヌおよびサ ルのミクロソームを用いて検討した。 その際, protease inhibitor として $0.5 \mathrm{mg} / \mathrm{m} l$ の trypsin inhibitor を 用いた. Fig. 1 に示すように，ヒトにおける小腸代謝 活性は最も高く, 次いでサルであり, ラットにおいて低 かった. CYP3A4のマーカーである testosterone $6 \beta$ hydroxylation 活性も同様にヒト $(1.58 \mathrm{nmol} / \mathrm{min} / \mathrm{mg}$ protein) で最も高く, 次いでサル(1.13) およびイヌ (0.15)であった28)。これらのことからサルはヒトに近い 代謝活性を有し, ヒト小腸代謝の評価に適した動物種で ある可能性が示唆された.

一方, A. Lampen らは cyclosporine の代謝活性の種 差についてヒトおよびブタの小腸ミクロソームを用いて 検討し, 両種においてほほ等しい $\mathrm{km}$ 值(3.9 vs 5.6 $\mu \mathrm{M})$ および $\mathrm{V}_{\max }(6.9$ vs $8.1 \mathrm{pmol} / \mathrm{min} / \mathrm{mg}$ protein $)$ が 得られることを明らかにした26)。さらに初期濃度とし て $6.7 \mu \mathrm{M}$ の cyclosporine に対する代謝活性は, ブタ (3.23 pmol $/ \mathrm{min} / \mathrm{mg}$ protein)に扔いて最も高く, 以下 イヌ(2.18)>ヒト(1.88)>ラット(0.75)の順であった.

Table I Kinetic parameters of CYP3A4 substrates in human small intestine and liver

\begin{tabular}{|c|c|c|c|c|c|c|c|}
\hline & \multirow{2}{*}{$\begin{array}{l}\text { Metabolic } \\
\text { pathway }\end{array}$} & \multicolumn{3}{|c|}{ Small intestine } & \multicolumn{3}{|c|}{ Liver } \\
\hline & & $\underset{(\mu \mathrm{M})}{\mathrm{Km}}$ & $\begin{array}{c}\mathrm{V}_{\max } \\
(\mathrm{pmol} / \mathrm{min} / \mathrm{mg})\end{array}$ & $\begin{array}{c}\mathrm{CL}_{\text {int }} \\
(\mu l / \mathrm{min} / \mathrm{mg})\end{array}$ & $\underset{(\mu \mathrm{M})}{\mathrm{Km}}$ & $\begin{array}{c}\mathrm{V}_{\max } \\
(\mathrm{pmol} / \mathrm{min} / \mathrm{mg})\end{array}$ & $\underset{(\mu l / \mathrm{min} / \mathrm{mg})}{\mathrm{CL}_{\text {int }}}$ \\
\hline Terfenadine $\mathrm{e}^{\mathrm{a})}$ & Hydroxylation & 2.5 & 61 & 24.4 & 1.8 & 370 & 205 \\
\hline Midazolam $^{\text {b) }}$ & $1^{\prime}$-hydroxylation & 3.58 & 463 & 129 & 2.75 & 1004 & 365 \\
\hline Oxodipine ${ }^{c)}$ & Oxidation & $30-50$ & $13-33$ & $0.26-1.1$ & 59 & 310 & 5.25 \\
\hline Lovastation $^{\mathrm{d})}$ & $6 \beta$-hydroxylation & 11.2 & 155.4 & 13.9 & 7.9 & 1576 & 199 \\
\hline Cyclosporine $\mathrm{e}^{\mathrm{e}}$ & AM-9 formation & 3.9 & 6.9 & 1.77 & 4.2 & 10.9 & 2.60 \\
\hline Rifabutin $^{\mathrm{f}}$ & $\begin{array}{l}\text { Total CYP mediat- } \\
\text { ed metab. }\end{array}$ & 12.5 & 103 & 8.24 & 10.9 & 105 & 9.63 \\
\hline Indinavirg) & Total metab. & 2.51 & 17.4 & 6.93 & 1.30 & 22.9 & 17.6 \\
\hline Tacrolimus ${ }^{\text {h) }}$ & $\begin{array}{l}\text { 13-o-demethyla- } \\
\text { tion }\end{array}$ & & $54^{\mathrm{j})}$ & & 6.9 & 66 & 9.6 \\
\hline Erythromycin ${ }^{\mathrm{i})}$ & Demethylation & & 1120 & & & 950 & \\
\hline
\end{tabular}

a) Raeissi D.S. et al.: pharm. Res. (1997), b) Thummel E.K. et al.: Clin Pharmacol. Ther. (1996), c) Flinois J.P. et al.: J. Pharmacol. Ther. Expt. (1991), d) Jacobsen W. et al. : J. Pharmacol. Exp. Thr. (1999), e) Lampen A. et al.: Pharmacology (1996), f) Iatsimirskaia E. et al. : Clin. Pharmacol. Ther., (1997), g) Chiba M. et al.: Biochem. Pharmacol. (1997), h) Lampen A. et al.: Drug Metab. Dispos. (1995), i) Watkins B.P. et al.: J. Clin. Invest. (1987), j) Initial concentration $=10 \mu \mathrm{M}$. 


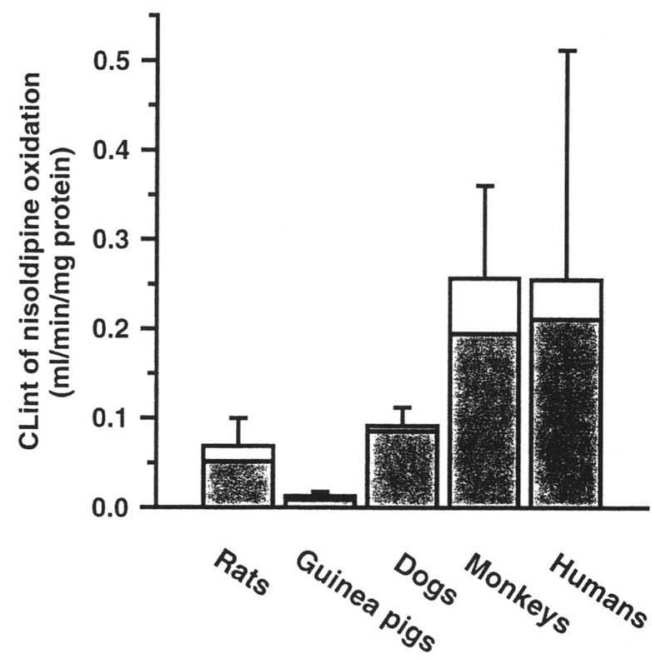

Fig. 1 CLint of nisoldipine metabolism in small intestinal microsomes of several animal species and humans. Closed and open columns indicated CLints for BAY o 3199 and BAY r 9425 being the primary metabolites, respectively.

Sirolimus(期濃度；10 $\mu \mathrm{M}$ ) についても同様にヒト (97.7 $\mathrm{pmol} / \mathrm{min} / \mathrm{mg}$ protein) およびブタ (77.2)で代謝活性は 高かった29).ブタの小腸代謝活性は代表的な CYP3A の 阻害剂により抑制され，その ki 值はヒト小腸ミクロソ 一ムでの值と同じレベルであった．このことはブタ小腸 代謝酵素がヒトと近い特徵を有していることを示唆して いる。.た, tacrolimusの小腸代謝活性もブタ $(60.3$ $\mathrm{pmol} / \mathrm{min} / \mathrm{mg}$ protein) 抢よびヒト(54.2)で高く, ラッ ト(14.3)で低い30)。以上の結果から, ラット小腸の CYP3A 濃度および代謝活性はヒトよりも低く, 現時点 ではサルおよびブタがヒトの小腸代謝を評価するのに適 した動物種であるといえる.

\section{3. 現状におけるヒトでの小腸代謝の評価}

cyclosporine の生体内利用率は $<5 \sim 89 \%$ と個体差か゚ 大きく, 有効血漿中濃度を維持するための臨床用量が患 者間で 10 倍以上の開きがある. 患者にCYP3A4 の阻 害剂である erythromycin を併用投与することにより生 体内利用率が上昇すること年から，この個体差は各患者 の初回通過代謝能に起因するものと考元られた. L.Z. Benet らのグループは健常人における cyclosporine $の$ 体内動態に及ぼす CYP3A の誘導剤(rifampin), または 阻害剤(ketoconazole)の併用投与の影響について検討 し4,5), 初回通過代謝に小腸代謝が寄与していることを 示した. 経口投与後の生体内利用率は誘導剤により $27 \%$ から 10\% へ減少し, 阻害剤により $22 \%$ から $56 \%$ へ増加した. 静脈内投与後の血漿中濃度から求めた Fh が誘導剤および阻害剤によりほとんど影響を受けなかっ たことから，この生体内利用率の変化は小腸代謝活性が
影響を受けたためであり, cyclosporine が顕著に小腸で 初回通過代謝を受けるものと結論付けた．同様の阻害剤 および誘導剤を用いた検討はそれぞれ tacrolimus ${ }^{6}$ 抢よ び verapamil ${ }^{7)}$ でも行われ, 初回通過代謝に対する CYP3A による小腸代謝の寄与が示されている.

CYP3A と P-glycoprotein (P-gp) が類似した基質特異 性を示すことが31)報告されている，P-gp が空腸の apical 側に高いレベルで発現していることから，P-gp およ びCYP3A が共に小腸における初回通過代謝に関与して いる可能性が考えられる.すなわち, enterocyteへ一 度吸収された薬物が P-gp により管空側へ汲出され再吸 収されることにより, enterocyteでのCYP3A4 に対す る薬物の暴露時間が増加し, 結果的に小腸代謝が促進さ

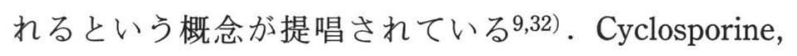
tacrolimus および verapamil は CYP3A に加え P-gp の

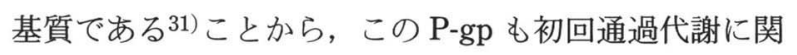
与しているかもしれない。

K. E. Thummel らは midazolam を健常人に静脈内投 与後, 血漿中濃度から求めた肝抽出率抢よび経口投与後 の生体内利用率を用いて小腸抽出率を算出した ${ }^{8)}$. 消化 管吸收率が良好であることからその小腸抽出率は $43 \%$ となり, 経口投与時において小腸が主な代謝部位である と考えられた. さらに, 移植患者に十二指腸内投与後, 門脈および動脈中未変化体および代謝物の濃度から midazolam の小腸抽出率が $43 \%$ であることを33)示した. Caco-2 cell を用いた透過実験において, midazolam は その透過に方向性が認められず P-gp によって輸送され ないこと触告されている. したがって, midazolam の小腸初回通過代謝には CYP3A4 のみが関与して いることになる.

これらのヒトにおける小腸代謝の評価は採血部位が静 脈に限られているため, 静脈内投与後の血漿中濃度から 求めた Fh 打よび経口投与後の生体内利用率を用いて $\mathrm{Fg} \cdot \mathrm{Fa}$ が算出されている. Lin らは9), この方法で求め た F わらず, 肝血流速が誘導剤および阻害剂において変動し ない, 経口吸収率が 100\% である, さらには静脈内投 与後の小腸代謝は無視できるなど, 多くの仮定があり, 小腸代謝が過大評価される危険性を指摘している ${ }^{9)}$. 初 回通過代謝に対する小腸代謝の寄与を明らかにするため にはまず動物を用いた詳細な検討が必要になる。

\section{4. 動物における小腸代謝の評価}

2. 項で示したように，現時点ではサルおよびブタが ヒト小腸代謝のモデル動物として適しているものと考光 られる。しかしながら, in vivo 実験のやりやすさ等を 考慮したとき，やはりラットでの実験が中心となるのは 致し方ないであろう。 
Y. Zhang らはP-gp およびCYP3Aの基質である $\mathrm{K} 02$ がラット小腸において初回通過代謝を受けるこ と35)を示した. Ketoconazole の併用投与は，K02 を静 脈内投与した後の血漿中濃度推移に影響を与えなかった が，経口投与後の生体内利用率を 2.9 から $31 \%$ へ増加 させた. Ketoconazole が MDR1-MDCK cell line にお ける K02 の basal から apical 側への透過よりも小腸代 謝活性を強く阻害したことから，この生体内利用率の上 昇が ketoconazole による P-gp の阻害ではなく，小腸代 謝の阻害に起因することを明らかにした．この結果は未 処理または誘導されたラットでの初回通過時における小 腸代謝の寄与を示しているが，ヒトでの試験と同様に間 接的な方法が用いられている.

Midazolam をラットに十二指腸内投与した後の生体 内利用率は, ketoconazole の併用投与により $11.5 \%$ か ら 52.6\% へ増加することから ${ }^{36)}$, F. Higashikawa らは mesentric vein からの採血を行い, midazolam のラット 小腸および肝臓における初回通過代謝を分離して定量的 に評価した ${ }^{36)}$. $50 \mathrm{nmol}$ の低用量では吸収量の $24.6 \%$ が小腸で代謝されるが， ketoconazole の併用投与によ りその代謝量が $10.3 \%$ へ減少することを明らかにした. また, CYP3Aの誘導剤である dexamethasone(DEX) を反復投与したラットでは, midazolam の小腸代謝の 程度が $49.0 \%$ へ増加していた 8,32 . ヒトでの小腸抽出 率が $43 \%$ であることから，DEX 処理したラットでは ヒトと同程度の小腸初回通過代謝を持つ可能性を示唆し ている.屯た，これより 10 倍高い投与量では小腸代謝 の程度が減少するが，これは肝臓と比較して経口吸収時 の小腸における $\mathrm{P} 450$ 近傍の薬物濃度が上昇し, 代謝能 が飽和したためであると推察された.

Hashimoto らは未処理のラットを用いて tacrolimus の生体内利用率に及ぼす小腸および肝代謝の影響につい て報告した ${ }^{37)}$. 門脈内投与後の血漿中濃度から求めた 肝抽出率および生体内利用率を用いて消化管内の抽出率 を $34.2 \%$ と算出した.さらに, everted sacにおける tacrolimus の消失が CYP3A の阻害剤により減少するこ とから，この初回通過代謝に CYP3A が関与している可 能性を示している. Tacrolimus を含めてこれら薬物の 定量的な in vitro 代謝活性は示されておらず, in vivo 小 腸抽出率を説明するのに十分なin vitro の活性が得られ るのか疑問が残る.

\section{In vitro から In vivo の予測について}

いくつかの薬物を除いてヒト小腸代謝活性が肝臓と比 較して低く, さらにラット小腸代謝活性はヒトに比らべ さらに低いことを示してきた。で゙，これらの活性で in vivoの初回通過代謝に対する小腸代謝の寄与を説明 できるのであろうか？ J. H. Lin らは indinavirの小腸
代謝について， in vitro から in vivoへの scaling を試み た ${ }^{38)}$. 未処理およびDEX 処理したラット小腸から得ら れた $\mathrm{V}_{\text {max }} / \mathrm{Km}$ 值を well stirred model に代入後, 得ら れた Egはそれぞれ 0.98 および $3.6 \%$ であった。これ らの值は, in vivoの $\mathrm{Eg}, 6.0 \%$ および $34 \%$ から大きく 乘離していた。 一方, ラット小腸ミクロソームを用いた phenacetin の実験では, in vitroの小腸代謝活性からの 予測值と実測值の一致すること吕が報告されている.

K. E. Thummel らは phenacetin の予測值と実測值が 一致したのは, protein binding が低いためである39) と した。すなわち, 経口吸収時において消化管から上皮細 胞への薬物の移行は血液側からの移行と異なり protein binding の影響を受けにくく, protein binding を考慮し ないモデルのほうが予測に適しているものと考えられ る. 彼らはその model を用いて, midazolamのヒトで の小腸代謝に関する in vitro から in vivo $\mathrm{Eg}$ の予測に成 功している. このような議論に対し, J. H. Lin らは indinavirの場合, protein binding が比較的低いにもかか わらず予測値と実測值が一致していないのは, むしろ P-gp が関与しているためである38) とした.このような in vitro-in vivo scaling を試みた報告は少なく, well stirred model の妥当性を含め議論される必要があろう.

以上, 小腸代謝の現状と問題点について簡単に述べ た. ヒトでの小腸代謝研究に比して動物での研究は少な く, この原因の一つとしてラットでの小腸代謝活性, 特 にCYP3A 活性が低いことと無関係ではないであろう. 今後, ラットでの小腸代謝に対する誘導剤の影響または 代謝活性の種差について検討が進み, ヒトと同様に CYP3A を発現した適切なる動物種が見い出され，これ らの問題に答えの出されることが待たれる.

\section{文献}

1) Klippert P., Borm P. and Noordhoek J.: Prediction of intestinal first-pass effect of phenacetin in the rat from enzyme kinetc data-correlation with in vivo data using mucosal blood flow. Biochem. Pharmacol., 31: 2545-2548 (1982).

2) Kolars C. J., Stetson L. P., Rush D. B., Ruwart J. M, Schmiedlin-Ren P., Duell A. E., Voorhees J. J., and Watkins B. P.: Cyclosprine metabolism P450IIIA in rat enterocytes-another determinant of oral bioavailability? Transplantation, 53: 596-602 (1992).

3) Gupta K. S., Bakran A., Johnson G. W. R. and Rowland M.: Erythromycin enhances the absorption of cyclosporine. Br. J. Clin. Pharmacol., 25: 401-402, (1988).

4) Hebert F. M., Robert P. J., Prueksaritatnont T., and Benet $Z$. L.: Bioavailability of cyclosporine with concomitant rifampin administration is markedky less than predicted by hepatic enzyme induction. Clin. Pharmacol. Ther., 52: 453-457 (1992).

5) Gomez Y. D., Wacher J. V., Tomlanovich J. S., Hebert F. $M$, and Benet Z. L.: The effects of ketoconazole on the in- 
testinal metabolism and bioavailability of cyclosproine. Clin. Pharmacol. Ther., 58: 15-19 (1995).

6) Floren C. L., Bekersky I, Benet Z. L., Mekki Q., Dressler D., Lee W. J., Roberts P. J., and Hebert F. M.: Tacrolimus oral bioavailability doubles with coadministration of ketoconazole. Clin Pharmacol. Ther., 62: 41-49 (1997).

7) Fromn F. M., Buss D., Kroemer K. H., and Eichelbaum M.: Differential induction of prehepatic and hepatic metabolism of verapamil by rifampin. Hepatology, 24: 796801 (1996).

8) Thummel E. K., O'Shea D., Paine F. M., Shen D. D., Kunze L. K., Perkins D. J., and Wilkinson R. G.: Oral first-pass elimination of midazolam involves both gastrointestinal and hepatic CYP3A-mediated metabolism. Clin. Pharmacol. Ther., 59: 491-502 (1996).

9) Lin H. J., Chiba M. and Baillie A. T.: Is the role of the small intestine in first-pass metabolism overemphasized? Pharmacol. Rev. 51: 135-157 (1999).

10) Hoensch H., Woo H. C, Raffin B. S., and Schmid R.: Oxidative metabolism of foreign compounds in rat small intestine: Cellular localization and dependence on dietrary iron. Gastroentrology, 70: 1063-1070 (1976).

11) Kaminshky S. L. and Fasco J. M.: Small intestine cytochromes P450. Toxicology, 21: 407-422 (1992).

12) Paine F. M., Khalighi M., Fisher M. J., Shen D. D., Kunze L. K., Marsh L. C., M. Perkins D. J., and Thummel E. K,: Characterization of interintestinal and intraintestinal variations in human CYP3A-dependent metabolism. J. Pharmacol. Exp. Ther., 283: 1552-1562 (1997).

13) Itatsimirskaia E., Tulebaev S., Storozhuk E., Utkin I., Smith D., Gerber N., and Koudriakova T.: Metabolism of rifabutin in human enterocyte and liver microsomes: kinetic parameters, identification of enzyme systems, and drug interactions with macrolides and antifungal agents. Clin. Pharmacol. Ther., 61: 554-562 (1997).

14) Watkins B. P., Wrighton A. S., Schuetz G. E. Molowa T. D., and Guzelian S. P.: Identification of glucocorticoid-inducible cytochromes $\mathrm{P}-450$ in the intestinal mucosa of rats and man. J. Clin. Invest., 80: 1029-1036 (1987).

15) Zhang Q.-Y., Dunbar D., Ostrowska A., Zeisloft S, Yang J., and Kaminsky S. L.: Characerization of human small intestinal cytochromes P-450. Drug Metab. Dispos., 27: 804809 (1999).

16) Bonkovky L. H., Hauri H.-P., Marti U., Gasser R., and Meyer A. U.: Cytochrome P450 of small intestinal epithelial cells. Gastroenterology, 88: 458-467 (1985).

17) Harmsworth L. W., and Franklin R. M.: Induction of hepatic and extrahepatic cytochrome $\mathrm{P}-450$ and monooxygenease activities by $\mathrm{N}$-substituted imidazoles. Xenobiotica, 20: 1053-1063 (1990).

18) Sesardic D., Cole J. K., Edwards J. R., Davies S. D., Thomas E. P., Levin W., and Boobis R. A.: The inducibility and catalytic activity of cytochromes P450c (P450IA1) and P450d (P450IA2) in rat tissues. Biochem. Pharmacol., 39: 499-506 (1990).

19) Rich J. K., Sesardic D., Foster R. J., Davies S. D., and Boodis R. A.: Immunohistochemical localization of cytochrome P450b/e in hepatic and extrahepatic tissues of the rat. Biochem. Phramacol., 38: 3305-3322 (1989).

20) Zhang Q.-Y., Wikoff J., Dunbar D., and Kaminsky L.: Characterization of rat small intestinal cytochrome P450 composition and inducibility. Drug Metab. Dispos., 24:
322-328 (1996).

21) Raeissi D. S., Guo Z., Dobson L. G., Artursson P., and Hidalgo J. I.: Comparision of CYP3A activities in a suclone of Caco-2 cells (TC7) and human intestines. Pharm. Res., 14: 1019-1025 (1997).

22) Flinois J.-P., Chabin M., Egros F., Dufour A., DE Waziers I., Mas-Chamberlin C., and Beaune H. P.: Metabolism rate of oxodipine in rats and humans: Comparison of in vivo and in vitro data. J. Pharmacol. Exp. Ther., 261: 381-386 (1991).

23) Jacobsen W., Kirchner G., Hallensleben K., Mancinelli L., Deters M., Hackbarth, I., Baner K., Benet Z. L., Sewing K.F., and Christians U.: Small intestinal metabolims of the 3-hydroxy-3-methylglutaryl-coenzyme A reductase inhibitor lovastatin and comparison with pravastatin. J. Pharmacol. Exp. Ther., 291: 131-139 (1999).

24) Chiba. M., Hensleigh M., and Lin H. J.: Hepatic and intestinal metabolism of indinavir, and HIV protease inhibitor, in rat and human microsomes. Biochem. Phamracol., 53: 1187-1195 (1997).

25) Lampen A., Christians U., Guengerich P. F., Watkins B. P., Kolars C. J., Bader A., Gonschior A.-K., Hackbarth I., and Sewing K.-F.: Metabolism of the immunosuppressant tacrolimus in the small intestine: Cytochrome P450, drug interactions, and interindividual variability. Drug Metab. Dispos., 23: 1315-1324 (1995).

26) Lampen A., Christians U., Bader A., Hackbarth I., and Sewing K.-F.: Dug interactions and interindividual variability of cyclosporin metabolism in the small intestine. Phamracology, 52: 159-168 (1996).

27) Lown S. K., Ghosh M., and Watkins B. P.: Sequences of intestinal and hepatic cytochrome P450 3A4 cDNAs are identical. Drug Metab. Dispos., 26: 185-187 (1998).

28) Prueksaritanont T., Gorham M. L., Hochman H. J., Tran O. L., and Vyas P. K.: Comparative studies of drugmetabolizing enzymes in dog, monkey, and human small intestines, and in Caco-2 cells. Drug Metab. Dispos., 24: 634642 (1996).

29) Lampen A., Zhang Y., Hackbarth I., Benet Z. L., Sewing K-F., and Charistians U.: Metabolism and transport of the macrolide immunosuprresssant sirolimus in the small intestine. J. Pharmacol. Exp. Ther., 285: 1104-1112 (1998).

30) Lampen A., Christians U., Gonschior A.-K., Bader A., Hackbarth I., von Engelhardd W., and Sewing K.-F.: Metabolism of the macrolide imunosuppressant, tacrolimus, by the pig gut mucosa in the Ussing chanber. $\mathrm{Br}$. J. Pharmacol., 117: 1734-1734 (1996).

31) Wacher J. V., Wu C.-Y., and Benet Z. L., Overlapping substrate specificities and tissue distribution of cytochrome P450 3A and P-glycoprotein: Implications for drug delivery and activity in cancer chemotherapy. Mol. Cancinogen., 13: 129-134 (1995).

32) Benet Z. L., Wu C.-Y., Hebert F. M., and Wacher J., V.: Intestinal drug metabolism and antitransport processes: A potential paradigm shift in oral drug delivery. J. Control. Release., 39: 139-143 (1996).

33) Paine F. M., Shen D. D., Kunze L. K., Perkins D. J., Marsh L. C., McVicar P. J., Barr M. D., Gillies S. B., and Thummel E. K.: Fisrt-pass metabolism of midazolam by the human intestine. Clin. Phamracol. Ther., 60: 14-24 (1996).

34) Kim B. R., Wandel C., Leake B., Cvetkovic M., Fromm F. 
M., Dempsey J. P., Roden M. M., Belas F., Chaulhary K. A., Roden M. D., Wood J. J. A., and Wilkinson R. G.: Interrelationship between substrates and inhibitiors of human CYP 3A and P-glycoprotein. Pharm. Res., 16: 408-413 (1999).

35) Zhang Y., Hsieh Y., Izumi T., Lin T. E., and Benet Z. L.: Effects of ketoconazole on the intestinal metabolism, transport and oral bioavailability of $\mathrm{K} 02$, a novel vinylsulfone peptidomimetic cysteine protease inhibitor and a P450 3A, $\mathrm{P}$-glycoprotein dual substrate, in male Sprague-Dawley rats. J. Pharmacol. Exp. Ther., 287: 246-252 (1998).

36) Higashikawa F., Murakami T., Kaneda T., Kato A., and Takano M.: Dose-dependent intestinal and hepatic firstpass metabolism of midazolam, a cytochrome P450 3A substrate with differently modulated enzyme activity in rats.
J. Pharm. Pharmacol., 51: 67-72 (1999).

37) Hashimoto Y., Sasa H., Shimomura M., and Inui K.: Effects of intestinal and hepatic metabolism on the bioavailability of tacrolimus in rats. Pharm. Res., 15: 1609-1613 (1998).

38) Lin H. J., Chiba M., Chen I-W., Nishime A. J., Deluna A. F., Yamazaki M., and Lin J. Y.: Effect of dexamethasone on the intestinal first-pass metabolism of indinavir in rats: Evidence of cytochrome $\mathrm{P}-450$ and P-glycoprotein induction. Drug Metab. Dispos., 27: 1187-1193 (1999).

39) Thummel E. K., Kunze L. K., and Shen D. D.: Enzymecatalyzed processes of first-pass hepatic and intestinal drug extraction. Adv. Drug Delivery Rev., 27: 99-127 (1997). 